\title{
Effect of Tocilizumab Therapy on Patient Outcome in Severe COVID-19 Pneumonia
}

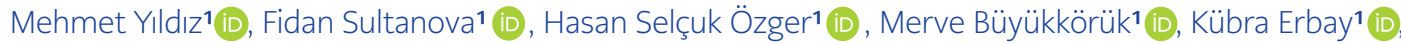 \\ Ümmügülsüm Gaygısız² (D), Abdurrahman Tufan ${ }^{3}$ iD, Özlem Gülbahar ${ }^{4}$ ID, Fatma Zehra Özcan ${ }^{1}$ (D), \\ Nazlı Elif Kuşcu ${ }^{1}$ (D), Deniz Gazioğlu' ${ }^{1}$ (D), Beyza Çifci ${ }^{1}$ (D), Fulya Şen ${ }^{1}$ (D), Esin Şenol ${ }^{1}$ (D), Kenan Hızel ${ }^{1}$ (D),

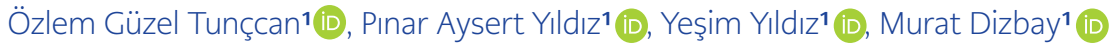 \\ 1 Department of Infectious Diseases and Clinical Microbiology, Gazi University School of Medicine, Ankara, Turkey \\ 2 Department of Anesthesiology and Reanimation, Gazi University School of Medicine, Ankara, Turkey \\ 3 Department of Internal Diseases, Rheumatology, Gazi University School of Medicine, Ankara, Turkey \\ 4 Department of Medical Biochemistry, Gazi University School of Medicine, Ankara, Turkey
}

\begin{abstract}
Background: This study aimed to evaluate the impact of tocilizumab treatment on clinical improvement in severe COVID-19 cases and the factors affecting clinical response.

Methods: This single-center, retrospective, descriptive study was conducted on severe COVID-19 patients. The ordinal scale of clinical status scores on the 0th, 1st, 3rd, and 7th days of tocilizumab treatment was calculated and compared for each patient. The ordinal scale of clinical status scores calculated on different days for the same patient was compared with Wilcoxon tests. The correlation between the clinical score and some laboratory parameters was evaluated by Pearson correlation analysis. Patients were grouped as responders and non-responders and compared by logistic regression analysis.

Results: Forty-two patients were enrolled in the study. The median of the ordinal scale of clinical status scores on the 0 th, 1st, $3 \mathrm{rd}$, and 7 th days of tocilizumab treatment were 6 (5 to 6), 6 (5 to 6), 6 (5 to 6), and 5 (4 to 7), respectively. When the clinical status scores on the 0 to 7 days of tocilizumab treatment were compared, the difference was statistically significant ( $p=0.024$, Wilcoxon). There was no statistically significant difference between day 0 and day 1 ( $\mathrm{p}=0.317$, Wilcoxon), day 0 and day 3 ( $\mathrm{p}=0.467$, Wilcoxon). By multivariate analysis, we determined that age ( OR: 0.91, 95\% 0.84-0.98) and respiratory rate (OR:0.78, 95\% 0.62-0.98) were factors affecting the response of tocilizumab treatment. No relationship was detected between laboratory parameters before tocilizumab treatment, including IL-6 levels and clinical response ( $\mathrm{p}=0.756$, Mann Whitney-U).

Conclusion: The use of tocilizumab in younger patients with low oxygen support increases the chance of clinical response after treatment. Since the effect of laboratory parameters in predicting the clinical response of tocilizumab is limited, treatment indications should be determined based on clinical parameters.
\end{abstract}

Keywords: COVID-19, tocilizumab treatment, cytokine storm
Corresponding Author:

Mehmet Yıldız

E-mail:

mhmt_0638@hotmail.com

Received: May 27, 2021

Accepted: July 27, 2021

Published: August 31, 2021

Suggested citation:

Yıldız M, Sultanova F, Özger HS, Büyükkörük M, Erbay K, Gaygısız Ü, et al. Effect of tocilizumab therapy on patient outcome in severe COVID-19 pneumonia. Infect Dis Clin Microbiol 2021; 2: 55-63.

DOI: 10.36519/idcm.2021.51 


\section{INTRODUCTION}

$\perp$ The COVID-19 pandemic emerged in Wuhan in December 2019 and spread rapidly all over the world. The number of cases worldwide reached a total of 150 million as of May 2021 (1). While $14 \%$ of these cases required hospitalization with severe pneumonia, 5\% required intensive care support. The mortality rate was shown as $2.3 \%$ (2).

Cytokine storm that might cause acute respiratory distress syndrome (ARDS), multiple organ failure, and mortality plays an important role in the course of severe COVID-19 cases (3). Interleukin-2 (IL-2), IL-2R, IL-4, IL-6, IL-8, IL-10, tumor necrosis factor-alpha (TNF- $\alpha$ ), and interferon-gamma (INF- $\gamma$ ) are associated with severe COVID-19 cases (3-5). Thus, anti-cytokine therapies are widely added to the standard treatments (such as antivirals, anticoagulants, corticosteroids) in COVID-19 cases (6).

The most commonly used anti-cytokine therapies are IL- 6 antagonists (tocilizumab). Although many clinical studies have evaluated the treatment efficacy of tocilizumab, different results have been reported about the treatment responses. In the initial published randomized controlled trials, no association was found between tocilizumab treatment and COVID-19 patient survival (7-9). However, contrary to those studies, tocilizumab has been associated with a lower frequency of intensive care unit (ICU) admissions, mechanical ventilation requirement, and mortality in recent randomized controlled trials and cohort studies based on real-life data (10-13). Based on the recent results, tocilizumab is identified among the suggested treatments for use in COVID-19 management guidelines $(14,15)$.

This study aimed to evaluate the impact of tocilizumab treatment on clinical improvement in severe COVID-19 cases and the factors affecting clinical response.

\section{METHODS}

\section{Study Design}

This single-center, retrospective, descriptive study was conducted in hospitalized severe COVID-19 patients between 20 March and 01 December 2020.

\section{Study Populations and Definitions}

All patients older than 18 years old who were admitted with a diagnosis of severe COVID-19 pneumonia or met the criteria of severe COVID-19 pneumonia at follow-up and whose standard COVID-19 treatment were added tocilizumab were included in the study. In addition to pneumonia confirmed by chest imaging, the presence of oxygen saturation $(\mathrm{SaO} 2) \leq 90 \%$, or the ratio of the partial pressure of oxygen to the fraction of inspired oxygen $(\mathrm{PaO} 2 / \mathrm{FiO} 2) \leq 300$, or respiratory rate $\geq 30$ per minute were considered as severe COVID-19 disease (16).

Standard treatment was defined as combination therapy consisting of antiviral (hydroxychloroquine or remdesivir favipiravir), corticosteroid (6 mg/day dexamethasone or $40 \mathrm{mg}$ /day prednisolone), and low molecular weight heparin (LMWH). Patients receiving treatment other than standard treatment before tocilizumab therapy (pulse corticosteroid, convalescent plasma, or IL-1 antagonist) were excluded from the study.

\section{Study Protocol}

During the study period, all eligible participants were enrolled consecutively. The patients' demographical features, clinical characteristics, and laboratory results (hemograms, serum, D-dimer, ferritin, CRP levels) were recorded on the first day of tocilizumab treatment. The ordinal scale of clinical status scores for each patient was calculated and recorded on the first day of tocilizumab treatment, as shown in

\section{HIGHLIGHTS}

- Cytokine storm plays an important role in the course of severe COVID-19 cases especially with acute respiratory distress syndrome (ARDS), multiple organ failure, and mortality

- The use of tocilizumab in younger patients with need low the oxygen support increases the chance of clinical responses after treatment

- The effect of laboratory parameters in predicting the clinical response of tocilizumab is limited, treatment indications should be determined based on clinical parameters. 


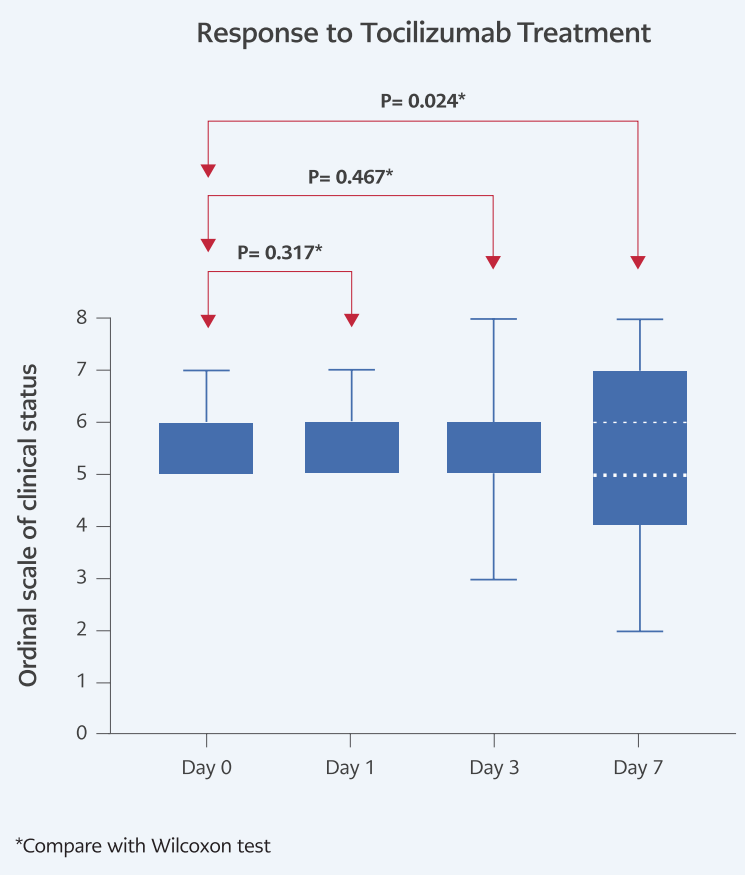

Figure 1. Clinical response to tocilizumab treatment.

Table 1 (17). The same scale score was calculated on the 1st, 3rd, and 7th days of tocilizumab treatment and compared with the onset score of treatment. A decrease in the ordinal scale of clinical status score of $\geq 2$ points was evaluated as a clinical response compared to the onset of treatment.

\section{Statistical Analysis}

All data were analyzed by IBM SPSS Statistics for Mac, version 25.0 for Mac OS X (IBM Corp., Armonk,
N.Y., USA). The normality of the data distribution was determined by the Shapiro-Wilk test, histogram, and Q-Q plots. The categorical values of the patients were expressed as a number and a percentage; the continuous values were presented as a mean and standard deviation (SD) or median values and an interquartile range (IQR) of $25 \%-75 \%$. The categorical values were analyzed with a chi-square test or Fisher exact test. The non-parametric values were analyzed using the Mann-Whitney U test and the parametric ones with the Student t-test. The ordinal scale of clinical status scores calculated on different days for the same patient was compared with Wilcoxon tests. The correlation between the clinical score changes between the 0 th and 7 th days of tocilizumab treatment and the changes in some laboratory parameters was evaluated by the Pearson correlation analysis. On the 7th day of tocilizumab treatment, patients were grouped as responders and non-responders and compared in terms of possible risk factors. Variables with a p-value of $<0.2$ in univariate analysis and not showing a high level of correlation with other variables were included in logistic regression models. When appropriate, 95\% confidence intervals ( $95 \%$ CIs) were also calculated, and statistical significance was set as $\mathrm{p}<0.05$.

\section{RESULTS}

Forty-two patients were enrolled in the study. The demographical, clinical, and laboratory findings of patients at hospital admission was shown in Table 2. The median of the ordinal scale of clinical status scores (day 0) of the patients on the tocilizumab

Table 1. The Ordinal scale of clinical status scores.

\begin{tabular}{|l|l|}
\hline Score & Clinical status \\
\hline 8 & Death \\
\hline 7 & Hospitalized, on invasive mechanical ventilation or extracorporeal membrane oxygenation (ECMO) \\
\hline 6 & Hospitalized, on non-invasive ventilation or high-flow oxygen devices \\
\hline 5 & Hospitalized, requiring low-flow supplemental oxygen \\
\hline 4 & Hospitalized, not requiring supplemental oxygen, but requiring ongoing medical care (related or not to Covid-19) \\
\hline 3 & Not hospitalized \\
\hline $1-2$ & \\
\hline
\end{tabular}


Table 2. Baseline characteristics of patients.

\begin{tabular}{|c|c|}
\hline Variables & $\mathrm{N}: 42$ \\
\hline Age, mean \pm SD & $61.76 \pm 14.07$ \\
\hline Male sex, n (\%) & $29(31)$ \\
\hline \multicolumn{2}{|l|}{ Comorbidities, n (\%) } \\
\hline Hypertension & $19(45.2)$ \\
\hline Cardiovascular disease & $5(11.9)$ \\
\hline Malignancy & $1(2.4)$ \\
\hline Diabetes mellitus & $13(31)$ \\
\hline Chronic obstructive pulmonary disease & $4(9.5)$ \\
\hline Chronic renal disease & $3(7.1)$ \\
\hline At least one comorbid disease & $25(59.5)$ \\
\hline At least two comorbid diseases & $10(23.8)$ \\
\hline \multicolumn{2}{|c|}{ Symptoms of patients on hospital admission, $\mathrm{n}(\%)$} \\
\hline Fever $\geq 38^{\circ} \mathrm{C}$ & $20(47.6)$ \\
\hline Cough & $25(59.5)$ \\
\hline Headache & $2(4.8)$ \\
\hline Sore throat & $2(4.8)$ \\
\hline Myalgia or fatigue & $13(31)$ \\
\hline Dyspnoea & $30(71.4)$ \\
\hline Diarrhea & $3(7.1)$ \\
\hline $\begin{array}{l}\text { Symptoms duration on hospital admission, } \\
\text { day, median (IQR \% } 25-75 \text { ) }\end{array}$ & 5 (3 to 7$)$ \\
\hline \multicolumn{2}{|l|}{ Clinical findings on hospital admission } \\
\hline Fever, $\geq 38$ n (\%) & $20(47.6)$ \\
\hline Respiratuar rate $\geq 30 / \mathrm{min}, \mathrm{n}(\%)$ & $13(31)$ \\
\hline SPO2 median (IQR \%25-75) & 88 (85 to 90$)$ \\
\hline FiO2, median (IQR \%25-75) & 27 (21 to 33 ) \\
\hline FiO2/PaO2, median (IQR \%25-75) & 185.5 (94 to 400$)$ \\
\hline \multicolumn{2}{|l|}{ Ordinary scale of clinical status score, $\mathrm{n}(\%)$} \\
\hline Score 5 & $14(33.3)$ \\
\hline Score 6 & $21(50.0)$ \\
\hline Score 7 & $7(16.7)$ \\
\hline \multicolumn{2}{|c|}{ Laboratory findings at hospital admission, median (IQR) } \\
\hline Leukocyte, $\mathrm{mm}^{3}$ & $\begin{array}{c}4.035 \\
(3.02 \text { to } 6.18)\end{array}$ \\
\hline
\end{tabular}

(Continued to Table 2)

\begin{tabular}{|c|c|}
\hline Lymphocyte, $\mathrm{mm}^{3}$ & 0.95 (0.69 to 1.22$)$ \\
\hline Hemoglobin, g/dl & 13.7 (12 to 14.2$)$ \\
\hline Platelet, $\times 10^{3}$ & $\begin{array}{c}158.5 \\
(127.5 \text { to } 197.5)\end{array}$ \\
\hline$A L T, I U / L$ & 31 (19 to 49.5$)$ \\
\hline AST, IU/L & 39.5 (31.5 to 72.5$)$ \\
\hline Creatinine, mg/dL & 0.97 (0.77 to 1.13$)$ \\
\hline D-dimer, $\mu \mathrm{g}$ & 0.7 (0.48 to 1.37$)$ \\
\hline Ferritin, ng/ml & 328 (179 to 646$)$ \\
\hline $\mathrm{LDH}, \mathrm{U} / \mathrm{L}$ & 329 (260 to 486$)$ \\
\hline CK, U/L & 133.5 (77.5 to 316.5$)$ \\
\hline CRP, mg/L & 81.8 (36.9 to 136.7$)$ \\
\hline PCT, ng/mL & 0.15 (0.08 to 0.40$)$ \\
\hline \multicolumn{2}{|l|}{ Antiviral tretament, $\mathrm{n} \%$} \\
\hline Favipiravir & $32(76.2)$ \\
\hline Favipiravir + HQ & $3(7.2)$ \\
\hline Favipiravir + Remdesivir & 7 (16.7) \\
\hline Corticosteroids, n \% & $42(100)$ \\
\hline \multicolumn{2}{|l|}{ Tocilizumab,n \% } \\
\hline $400 \mathrm{mg}$ & $10(23.8)$ \\
\hline $800 \mathrm{mg}$ & $32(76.2)$ \\
\hline
\end{tabular}

IQR: Inter-quartile range; SD: Standard deviation; FiO2: Fraction of inspired oxygen; SPO2: Oxygen saturation; PaO2: Partial pressure of oxygen; ALT: Alanine aminotransferase; AST: Aspartate aminotransferase; LDH: Lactate dehydrogenase; CK: Creatine kinase; CRP: C-reactive protein; HQ: Hydroxychloroquine

treatment days was 6 (5 to 6 ). The median of the ordinal scale of clinical status scores on the 1st, 3rd, and 7 th days of tocilizumab treatment were 6 ( 5 to 6), 6 (5 to 6), and 5 (4 to 7), respectively. According to the comparison of the ordinal scale of clinical status score, there was no statistically significant difference between day 0 and day 1 ( $\mathrm{p}=0.317$, Wilcoxon, figure 1$)$, day 0 and day 3 ( $p=0.467$, Wilcoxon, as shown in the figure). When compared with the ordinal scale of clinical status score on day 0 of tocilizumab treatment, a statistically significant difference was found on the 7th day ( $p=0.024$, Wilcoxon, as shown in the figure). Median of lymphocyte counts, ferritin, CRP, D-dimer levels on day 0 of tocilizumab treatment were 0.70 (0.48 
Table 3. Comparison of the responders and non-responders on the $7^{\text {th }}$ day of tocilizumab treatment.

\begin{tabular}{|c|c|c|c|c|c|}
\hline & $\begin{array}{l}\text { Responders on } \\
7^{\text {th }} \text { day of } \\
\text { treatment } n=11\end{array}$ & $\begin{array}{l}\text { Non-responders on } 7^{\text {th }} \\
\text { day of teratment } \\
n=31\end{array}$ & $\begin{array}{c}P \\
\text { value }\end{array}$ & $\begin{array}{l}\text { Unadjusted } \\
\text { OR }\end{array}$ & Adjusted OR \\
\hline Age, mean \pm SD & $52.5 \pm 13.4$ & $65 \pm 12.8$ & 0.09 & $\begin{array}{c}0.93 \\
(0.87 \text { to } 0.98)\end{array}$ & $\begin{array}{c}0.91 \\
(0.84 \text { to } 0.98)\end{array}$ \\
\hline Male sex, n (\%) & $8(72.2)$ & $21(67.7)$ & 0.99 & $\begin{array}{c}0.78 \\
(0.17 \text { to } 3.62)\end{array}$ & - \\
\hline \multicolumn{6}{|l|}{ Comorbidities, n (\%) } \\
\hline Diabetes mellitus & $3(27.3)$ & $10(32.3)$ & 0.99 & $\begin{array}{c}0.75 \\
(0.27 \text { to } 5.8)\end{array}$ & - \\
\hline Hypertension & $4(36.4)$ & $15(48.4)$ & 0.73 & $\begin{array}{c}0.61 \\
(0.14 \text { to } 2.5)\end{array}$ & - \\
\hline Cardiovascular disease & $1(9.1)$ & $4(12.9)$ & 0.99 & $\begin{array}{c}0.67 \\
(0.06 \text { to } 6.7)\end{array}$ & - \\
\hline Malignancy & - & $1(3.2)$ & NA & NA & - \\
\hline Chronic Kidney disease & $1(9.1)$ & $(6.5)$ & 0.99 & $\begin{array}{c}0.69 \\
(0.05 \text { to } 8.4)\end{array}$ & - \\
\hline At least one comorbid disease & $6(54.5)$ & $19(61.3)$ & 0.73 & $\begin{array}{c}1.3 \\
(0.32 \text { to } 5.3)\end{array}$ & - \\
\hline $\begin{array}{l}\text { Duration of COVID-19 related } \\
\text { symptoms on the day of } \\
\text { tocilizumab treatment }\end{array}$ & 9 (8 to 14$)$ & 10 (8 to 11$)$ & 0.76 & $\begin{array}{c}1.03 \\
(0.96 \text { to } 1.09)\end{array}$ & - \\
\hline \multicolumn{6}{|c|}{ Clinical findings on the day of tocilizumab treatment } \\
\hline Fever $\left(\geq 38^{\circ} \mathrm{C}\right)$, $(\mathrm{n} \%)$ & $2(18.2)$ & $4(12.9)$ & 0.64 & $\begin{array}{c}0.66 \\
(0.10 \text { to } 4.27)\end{array}$ & - \\
\hline $\begin{array}{l}\text { Respiratory rate, median } \\
\text { (IQR, } 25 \text { to } 75 \%)\end{array}$ & $28(28$ to 30$)$ & $30(30$ to 36$)$ & 0.03 & $\begin{array}{c}0.82 \\
(0.67 \text { to } 1)\end{array}$ & $\begin{array}{c}0.78 \\
(0.62 \text { to } 0.98)\end{array}$ \\
\hline FiO2, median (IQR, 25 to $75 \%$ ) & 30 (24 to 35$)$ & 60 (36 to 80$)$ & $<0.001$ & $\begin{array}{c}0.9 \\
(0.83 \text { to } 0.97)\end{array}$ & NA \\
\hline $\mathrm{PaO} 2$ /FiO2 & 192 (166 to 245$)$ & 105 (68 to 185$)$ & 0.003 & $\begin{array}{c}1.01 \\
(1 \text { to } 1.01)\end{array}$ & $\begin{array}{c}1 \\
(0.99 \text { to } 1.01)\end{array}$ \\
\hline \multicolumn{6}{|c|}{ Oxygen support on the day of tocilizumab, n (\%) } \\
\hline Mechanical ventilation & $1(9.1)$ & $8(25.8)$ & \multirow{3}{*}{ NA } & \multirow{3}{*}{ NA } & \multirow{3}{*}{-} \\
\hline High flow oxygen therapy & - & $11(35.5)$ & & & \\
\hline Other oxygen supports & $10(90.9)$ & $12(38.7)$ & & & \\
\hline $\begin{array}{l}\text { Ordinal Scale of clinical status } \\
\text { scores on the day of tocilizumab }\end{array}$ & $5(5$ to 6$)$ & $6(5$ to 6$)$ & 0.138 & $\begin{array}{c}0.40 \\
(0.13 \text { to } 1.24)\end{array}$ & $\begin{array}{c}1.24 \\
(0.29 \text { to } 5.26)\end{array}$ \\
\hline \multicolumn{6}{|c|}{ Laboratory findings on the day of tocilizumab treatment } \\
\hline White blood cell, $\mathrm{mm}^{3}$, mean $\pm \mathrm{SD}$ & $7.91 \pm 3.27$ & $8.63( \pm 4.01)$ & 0.597 & $\begin{array}{c}0.94 \\
(0.78 \text { to } 1.14)\end{array}$ & - \\
\hline Lymphocyte, mm3 & $1(0.79$ to 1.1$)$ & 0.61 (0.43 to 0.82$)$ & 0.017 & $\begin{array}{c}2.31 \\
(0.59 \text { to } 9.04)\end{array}$ & $\begin{array}{c}3.07 \\
(0.49 \text { to } 18.9)\end{array}$ \\
\hline D-dimer, $\mu g / m L$ & $0.62(0.35$ to 1.67$)$ & $0.87(0.48$ to 1.5$)$ & 0.463 & $\begin{array}{c}1.18 \\
(0.90 \text { to } 1.56)\end{array}$ & - \\
\hline
\end{tabular}


(Continued to Table 3)

\begin{tabular}{|c|c|c|c|c|c|}
\hline Ferritin, ng/mL & 404 (329 to 537) & 526 (308 to 845$)$ & 0.396 & $\begin{array}{c}0,99 \\
(0.99 \text { to } 1)\end{array}$ & - \\
\hline $\mathrm{CRP}, \mathrm{mg} / \mathrm{dL}$ & $83.85( \pm 47.76)$ & $102.65( \pm 62.2)$ & 0.369 & $\begin{array}{c}0.99 \\
(0.98 \text { to } 1)\end{array}$ & - \\
\hline $\mathrm{IL}-6 \mu \mathrm{g} / \mathrm{ml}$ & 140 (45 to 212$)$ & 159.4 (56.2 to 349.2$)$ & 0.756 & $\begin{array}{c}0.99 \\
\text { (0.99 to } 1)\end{array}$ & - \\
\hline \multicolumn{6}{|l|}{ Antiviral therapy, n (\%) } \\
\hline Favipiravir & $10(90.9)$ & $22(71)$ & \multirow{3}{*}{0.368} & \multirow{3}{*}{$\begin{array}{c}2.27 \\
(0.28 \text { to } 25.7)\end{array}$} & \\
\hline Favipiravir + HQ & 0 & $3(9.7)$ & & & \\
\hline Favipiravir + Remdesivir & $1(9.1)$ & $6(19.4)$ & & & \\
\hline $\begin{array}{l}\text { Duration of corticosteroid } \\
\text { treatment on the day of } \\
\text { tocilizumab treatment }\end{array}$ & $5(1$ to 5$)$ & $4(2$ to 4$)$ & 0.844 & $\begin{array}{c}0.97 \\
\text { (0.77 to } 1.21)\end{array}$ & - \\
\hline $\begin{array}{l}\text { Total dose of tocilizumab (mg), } \\
\text { median (IQR, } 25 \text { to } 75 \% \text { ) }\end{array}$ & $\begin{array}{l}800 \\
\text { (400 to } 800)\end{array}$ & $\begin{array}{c}800 \\
\text { (800 to } 800)\end{array}$ & 0.652 & & \\
\hline
\end{tabular}

IQR: Inter-quartile range; SD: Standard deviation; FiO2: Fraction of inspired oxygen; SPO2: Oxygen saturation;

PaO2: Partial pressure of oxygen; CRP: C-reactive protein; IL: Interleukin; HQ: Hydroxychloroquine

Table 4. Outcomes of patients.

\begin{tabular}{|c|c|c|c|}
\hline & $\begin{array}{c}\text { Responders } \\
\mathrm{n}=11\end{array}$ & $\begin{array}{c}\text { Non-responders } \\
n=31\end{array}$ & $P$ value \\
\hline ICU support, n (\%) & $5(45.5)$ & $25(80.6)$ & 0.049 \\
\hline Invasive mechanical ventilation, $\mathrm{n}(\%)$ & $1(9.1)$ & $11(35.5)$ & 0.133 \\
\hline Duration of hospitalization, IQR (25-75\%) & $6(5$ to 13$)$ & 17 (12 to 25$)$ & $<0.001$ \\
\hline Duration of ICU stay, median IQR (25-75\%) * & 5 (2 to 22.5$)$ & 11 (9.5 to 21$)$ & 0.019 \\
\hline Mortality ( $28^{\text {th }}$ day) & - & $13(41.9)$ & NA \\
\hline Secondary nozocomial bacterial infection, $\mathrm{n}(\%)$ & $1(9.1)$ & $13(41.9)$ & 0.067 \\
\hline Antibiotic therapy $\mathrm{n}(\%)$ & $7(63.6)$ & $29(93.5)$ & 0.032 \\
\hline
\end{tabular}

IQR: Inter-quartile range; ICU: Intensive care units

*Evaluated for 30 patients

to 1.00$), 499$ (315 to 667$), 91.4$ (52.7 to 136.5$)$ and 0.71 (0.45 to 1.54 ), respectively. The median of lymphocyte counts, ferritin, CRP, D-dimer levels on the $7^{\text {th }}$ day of tocilizumab treatment was previously 0.90 (0.74-1.52), 350 (350-428), 5.04 (3.92 - 6.76), and $2.05(81.03-2.05)$. There was a significant difference in lymphocyte counts $(\mathrm{p}<0.001$, Wilcoxon), ferritin ( $p=0,03$, Wilcoxon), CRP ( $<<0.001$, Wilcoxon) and $\mathrm{D}$-dimer ( $\mathrm{p}=0.05$, Wilcoxon) levels between days 0 and 7 of tocilizumab. The correlation between the differences in the ordinal scale of clinical status score and the differences in lymphocyte count, ferritin, CRP, and D-dimer between the 0th and 7th days of tocilizumab treatment was evaluated and the Pearson correlation coefficient was $-0.179(\mathrm{p}=0.255)$, -0.205 ( $\mathrm{p}=0.193),-0.70$ (0.48 to 1.00$),-0.174(\mathrm{p}=0.269)$, 0.70 (0.48 to 1.00$), 0.320$ ( $\mathrm{p}=0.039)$, respectively.

On the 7th day of tocilizumab treatment, the clinical response rate was $26.2 \% \quad(n=11)$. The patients were grouped as responders and nonresponders according to their clinical responses on the 7th day and compared possible risk factors, as shown in Table 3. Age (OR: 0.91, 95\% 0.84-0.98) and 
respiratory rate (OR: $0.78,95 \% 0.62-0.98)$ at the time of treatment were determined as factors affecting tocilizumab treatment response. Responders and non-responders were compared in terms of 28day mortality, ICU support requirement, invasive mechanical ventilation, intensive care and hospital stay, secondary bacterial infection, and antibiotic use, as shown in Table 4.

\section{DISCUSSION}

In our study, tocilizumab treatment was related to clinical improvement in one-fourth of severe COVID-19 cases. Being young and having low oxygen requirements (low respiratory rate and low oxygen requirement) is associated with the tocilizumab response. Patients with clinical improvement stayed shorter in hospital and ICU, needed low ICU support, and resulted in low mortality rates. No relationship was detected between laboratory parameters before tocilizumab treatment, including IL-6 levels, and clinical response.

In initial randomized controlled trials that used different inclusion and outcome criteria, the effect of tocilizumab treatment on patients' survival was not detected $(8,9,13,18,19)$. However, observational studies evaluating the efficacy of tocilizumab and meta-analysis of these studies showed that the tocilizumab therapy was associated with decreased oxygen support, mechanical ventilation requirement, and mortality rates $(6,7,20-27)$. Current randomized controlled trials support this real-life observational data. In recent randomized trials, tocilizumab treatment is associated with shorter hospital and ICU stays reduced need for mechanical ventilation, and prolonged survival (10-13).

In the first week of the treatment, we achieved clinical improvement in one-fourth of the patients with tocilizumab therapy. However, we could not demonstrate the effect of tocilizumab on clinical improvement in the early period (day 1 and day 3 ) of treatment.

In some studies, the time of adding tocilizumab to the standard therapy was associated with the clinical response. The use of tocilizumab in the early period increased clinical response rates in patients with lower oxygen requirements, especially before the need for intensive care support or mechanical ventilation $(8,21,25,28,30)$. Similarly, our study found that the frequency of clinical response increased with the use of treatment tocilizumab in young patients with lower oxygen requirements (low respiratory rate and high $\mathrm{PaO} 2$ / FiO2). However, there was no relationship between tocilizumab treatment response and the duration of COVID-19 symptoms. Therefore, tocilizumab should be added early based on clinical evaluation and increase in oxygen supply rather than disease and symptom duration.

Laboratory values such as ferritin, CRP, D-dimer, LDH, IL-6 levels, which are used to identify cytokine storm and are associated with severe disease and poor prognosis, are widely used for tocilizumab treatment indications $(21,29,31-33)$. Current guidelines recommend CRP $75 \mathrm{mg} / \mathrm{L}$ cutoff values for defining systemic inflammation and the indication for tocilizumab therapy in severe COVID-19 patients $(14,15)$. However, the effect of these laboratory values in predicting the clinical response to tocilizumab treatment and the uncertainties in the limit values to be used for the treatment indication remain. In the study of Fernadez-Luiz et al., no relationship was shown between laboratory parameters other than LDH and clinical response to tocilizumab (7). Also, in our study, there was no relationship between the pre-treatment laboratory parameters of tocilizumab, including IL-6, and clinical response to tocilizumab.

One of the concerns for tocilizumab treatment in COVID-19 patients is the increased risk of secondary bacterial and fungal infections. In some small cohort studies, tocilizumab was associated with secondary nosocomial infections, especially when used in combination with steroids (34-36). However, there was no relationship between secondary infection and tocilizumab in randomized controlled studies and meta-analysis (6). In our study, secondary bacterial infection developed in one-third of the patients who received tocilizumab treatment. However, due to the absence of a comparison group in our study, the effect of tocilizumab use on the development of secondary bacterial infection could not be evaluated. 
Our study has some limitations. First, since only patients using tocilizumab were included in the study, no comparison could be made regarding efficacy, side effects, and development of complications. Second, because there was no control group, we could not rule out the possibility that our results are dependent on the natural course of the disease or some known prognostic factors (such as age). Finally, because the study was based on the limited number of patient data from a single-center, obtained statistical results had a high risk of type 2 errors, and therefore the results could not be generalized.

In conclusion, using tocilizumab in younger patients who need low oxygen support increases clinical responses after treatment. However, since the effect of laboratory parameters in predicting the clinical response of tocilizumab is limited, treatment indications should be determined based on clinical parameters.
Ethical Approval: Clinical Studies Ethical Committee of Gazi University Faculty of Medicine approved the study on April 19, 2020, with decision number 398.

Informed Consent: This single-center, retrospective, descriptive study was conducted in hospitalized severe COVID-19 patients between 20 March and 01 December 2020. So, there was no need for written informed consent.

Peer-review: Externally peer-reviewed

Author Contributions: Concept - M.Y., H.S.Ö., F.S., M.B., K.E., Ü.G.; Design - M.Y., H.S.Ö., F.S., M.B., K.E., Ü.G.; Supervision - E.Ş., M.D.,
Ö.G.T., Y.Y., Ö.G., A.T., K.H.; Funding - F.Ş., F.Z.Ö., N.E.K., B.Ç., Ö.G.; Materials - F.Ş., F.Z.Ö., N.E.K., B.Ç., Y.Y.; Data Collection and/or Processing - P.A.Y., F.S.., Ö.G., F.Z.Ö., N.E.K., B.Ç.; Analysis and/or Interpretation - A.T., E.Ş., M.D., K.H., Ö.G.T., P.A.Y., Y.Y.; Literature Review - A.T., E.Ş., M.D., K.H., Ö.G.T., P.A.Y., Y.Y.; Writer - M.Y., H.S.Ö., F.S., M.B., K.E., Ü.G.;

Conflict of Interest: The authors have no conflict of interest to declare.

Financial Disclosure: The authors declared that this study has received no financial support.

\section{REFERENCES}

1 WHO Coronavirus (COVID-19) Dashboard [Internet]. World Health Organization. (cited May 2021). Available from: https:// covid19.who.int/

2 Wu Z, McGoogan JM. Characteristics of and important lessons from the coronavirus disease 2019 (COVID-19) outbreak in China: summary of a report of 72314 cases from the chinese center for disease control and prevention. JAMA. Apr 7, 2020;323(13):1239-42. [CrossRef]

3 Mulchandani R, Lyngdoh $\mathrm{T}$, Kakkar AK. Deciphering the COVID-19 cytokine storm: systematic review and meta-analysis. Eur J Clin Invest. Jan, 2021;51(1):e13429. [CrossRef]

4 Akbari H, Tabrizi R, Lankarani KB, Aria H, Vakili S, Asadian F, et al. The role of cytokine profile and lymphocyte subsets in the severity of coronavirus disease 2019 (COVID-19): a systematic review and meta-analysis. Life Sci. 2020;258:118167. [CrossRef]

5 Yan W, Chen D, Bigambo FM, Wei H, Wang X, Xia Y. Differences of blood cells, lymphocyte subsets and cytokines in COVID-19 patients with different clinical stages: a network meta-analysis. BMC Infect Dis. Feb 8, 2021;21(1):156. CrossRef

6 Tleyjeh IM, Kashour Z, Damlaj M, Riaz M, Tlayjeh H, Altannir M, et al. Efficacy and safety of tocilizumab in COVID-19 patients: a living systematic review and meta-analysis. Clin Microbiol Infect. Feb, 2021; 27(2): 215-27. [CrossRef]
7 Fernández-Ruiz M, López-Medrano F, Pérez-Jacoiste Asín MA, Maestro de la Calle G, Bueno H, Caro-Teller JM, et al. Tocilizumab for the treatment of adult patients with severe COVID-19 pneumonia: A single-center cohort study. J Med Virol. Feb, 2021; 93(2):831-42. [CrossRef]

8 Hermine O, Mariette X, Tharaux PL, Resche-Rigon M, Porcher $\mathrm{R}$, Ravaud $\mathrm{P}$, et al. Effect of tocilizumab vs usual care in adults hospitalized with COVID-19 and moderate or severe pneumonia: a randomized clinical trial. JAMA Intern Med. Jan 1, 2021;181(1):32-40. [CrossRef]

9 Veiga VC, Prats JAGG, Farias DLC, Rosa RG, Dourado LK, Zampieri FG, et al. Effect of tocilizumab on clinical outcomes at 15 days in patients with severe or critical coronavirus disease 2019: randomised controlled trial. BMJ. Jan 20, 2021;372:n84. [CrossRef]

10 RECOVERY Collaborative Group. Tocilizumab in patients admitted to hospital with COVID-19 (RECOVERY): a randomised, controlled, open-label, platform trial. Lancet. May 1, 2021; 397: 1637-45. [CrossRef]

11 REMAP-CAP Investigators, Gordon AC, Mouncey PR, Al-Beidh F, Rowan KM, Nichol AD, et al. Interleukin-6 receptor antagonists in critically ill patients with Covid-19. N Engl J Med. April 22, 2021;384(16):1491-1502. [CrossRef] 
12 Rosas IO, Bräu N, Waters M, Go RC, Hunter BD, Bhagani S, et al. Tocilizumab in hospitalized patients with severe Covid-19 pneumonia. N Engl J Med. 2021;384:1503-16. [CrossRef]

13 Salama C, Han J, Yau L, Reiss WG, Kramer B, Neidhart JD, et al. Tocilizumab in patients hospitalized with Covid-19 pneumonia. N Engl J Med. 2021;384:20-30. [CrossRef]

14 Interleukin-6 inhibitors [Internet]. COVID-19 Treatment Guidelines Panel. Coronavirus Disease 2019 (COVID-19) Treatment Guidelines. National Institutes of Health. (updated April 21, 2021; cited May 15, 2021). Available from: https://www. covid19treatmentguidelines.nih.gov/therapies/immunomodulators/interleukin-6-inhibitors/

15 Bhimraj A, Morgan RL, Shumaker AH, Lavergne V, Baden L, Cheng VC, et al. IDSA Guidelines on the Treatment and Management of Patients with COVID-19 [Internet]. Infectious Diseases Society of America. (updated March 3, 2021; cited May 27, 2021). Available from: https://www.idsociety.org/practice-guideline/covid-19-guideline-treatment-and-manage$\underline{\text { ment }}$

16 COVID-19 Clinical management: Living guidance [Internet] World Health Organization. (January 25, 2021; cited May 27, 2021). Available from: https://www.who.int/publications/i/ item/WHO-2019-nCoV-clinical-2021-1

17 Spinner CD, Gottlieb RL, Criner GJ, Arribas López JR, Cattelan AM, Soriano Viladomiu A, et al. Effect of remdesivir vs standard care on clinical status at 11 days in patients with moderate COVID-19: a randomized clinical trial. JAMA. 2020;324:1048-57. [CrossRef]

18 Stone JH, Frigault MJ, Serling-Boyd NJ, Fernandes AD, Harvey L, Foulkes AS, et al. Efficacy of tocilizumab in patients hospitalized with Covid-19. N Engl J Med. 2020;383: 2333-44. [CrossRef]

19 Salvarani C, Dolci G, Massari M, Merlo DF, Cavuto S, Savoldi L, et al. Effect of tocilizumab vs standard care on clinical worsening in patients hospitalized with COVID-19 pneumonia: A randomized clinical trial. JAMA Intern Med. 2021;181:24-31. [CrossRef]

20 Berardicurti O, Ruscitti P, Ursini F, D’Andrea S, Ciaffi J, Meliconi R, et al. Mortality in tocilizumab-treated patients with COVID-19: a systematic review and meta-analysis. Clin Exp Rheumatol. 2020;38:1247-54.

21 Hassoun A, Thottacherry ED, Muklewicz J, Aziz QU, Edwards J. Utilizing tocilizumab for the treatment of cytokine release syndrome in COVID-19. J Clin Virol. 2020;vol.128, p.104443.

22 Malekzadeh R, Abedini A, Mohsenpour B, Sharifipour E, Ghasemian R, Javad-Mousavi SA, et al. Subcutaneous tocilizumab in adults with severe and critical COVID-19: A prospective open-label uncontrolled multicenter trial. Int Immunopharmacol. 2020;89:107102. [CrossRef]

23 Malgie J, Schoones JW, Pijls BG. Decreased mortality in coronavirus disease 2019 patients treated with tocilizumab: A rapid systematic review and meta-analysis of observational studies Clin Infect Dis. 2021;72:e742-e749. [CrossRef]
24 Okoh AK, Bishburg E, Grinberg S, Nagarakanti S. Tocilizumab use in COVID-19-associated pneumonia. J Med Virol. 2021; 93:1023-28. [CrossRef]

25 Perrone F, Piccirillo MC, Ascierto PA, Salvarani C, Parrella R, Marata AM, et al. Tocilizumab for patients with COVID-19 pneumonia. The single-arm TOCIVID-19 prospective trial. J Transl Med. 2020;18:405. [CrossRef]

26 Tian J, Zhang M, Jin M, Zhang F, Chu Q, Wang X, et al. Repurposed tocilizumab in patients with severe COVID-19. J Immunol. 2021;206:599-606. [CrossRef]

27 Toniati P, Piva S, Cattalini M, Garrafa E, Regola F, Castelli F, et al. Tocilizumab for the treatment of severe COVID-19 pneumonia with hyperinflammatory syndrome and acute respiratory failure: A single center study of 100 patients in Brescia, Italy. Autoimmun Rev. 2020;19:102568. [CrossRef]

28 Gupta S, Wang W, Hayek SS, Chan L, Mathews KS, Melamed ML, et al. Association between early treatment with tocilizum$\mathrm{ab}$ and mortality among critically ill patients with COVID-19. JAMA Intern Med. 2021;181:41-51. [CrossRef]

29 Nugroho CW, Suryantoro SD, Yuliasih Y, Rosyid AN, Asmarawati TP, Andrianto L, et al. Optimal use of tocilizumab for severe and critical COVID-19: a systematic review and meta-analysis. F1000Res. Feb 4, 2021;10:73. [CrossRef]

30 Menzella F, Fontana M, Salvarani C, Massari M, Ruggiero P, Scelfo C, et al. Efficacy of tocilizumab in patients with COVID-19 ARDS undergoing noninvasive ventilation. Crit Care. 2020;24:589. [CrossRef]

31 Rodríguez-Baño J, Pachón J, Carratalà J, Ryan P, Jarrín I, Yllescas $\mathrm{M}$, et al. Treatment with tocilizumab or corticosteroids for COVID-19 patients with hyperinflammatory state: a multicentre cohort study (SAM-COVID-19). Clin Microbiol Infect. 2021;27:244-52. [CrossRef]

32 Aziz M, Fatima R, Assaly R. Elevated interleukin-6 and severe COVID-19: A meta-analysis. J Med Virol. 2020;92:2283-5. [CrossRef]

33 Coomes EA, Haghbayan H. Interleukin-6 in Covid-19: a systematic review and meta-analysis. Rev Med Virol. 2020;30:1-9. [CrossRef]

34 Giacobbe DR, Battaglini D, Ball L, Brunetti I, Bruzzone B, Codda $\mathrm{G}$, et al. Bloodstream infections in critically ill patients with COVID-19. Eur J Clin Invest. 2020;50:e13319. [CrossRef]

35 Kimmig LM, Wu D, Gold M, Pettit NN, Pitrak D, Mueller J, et al. IL-6 inhibition in critically ill COVID-19 patients is associated with increased secondary infections. Front Med (Lausanne). 2020;7:583897. [CrossRef]

36 Kumar G, Adams A, Hererra M, Rojas ER, Singh V, Sakhuja A, et al. Predictors and outcomes of healthcare-associated infections in COVID-19 patients. Int J Infect Dis. 2021;104:287-92. [CrossRef] 